\title{
CHRO firm dinosaur versus CHRO role gorilla: the effect of CHRO company and role tenure on firms' social performance
}

\author{
Nina Engels ${ }^{1}$ (D) Denise Fischer-Kreer ${ }^{1}$ D $\cdot$ Malte Brettel $^{1}$
}

Accepted: 15 November 2021 / Published online: 29 November 2021

(c) The Author(s) 2021, corrected publication 2021

\begin{abstract}
Academics and practitioners emphasize the rising importance of Chief Human Resource Officers (CHROs). CHROs act as heads of staff-they motivate the personnel and offer guidance. This study helps clarify the impact of increasingly relevant CHROs and reveals how their company and role tenure influence firms' social performance. Drawing on a multisource longitudinal dataset of S\&P 500 firms, we empirically validate our hypotheses. The sample contains 283 companies with 1944 firm-year observations from 2005 to 2017 and combines manually collected top management team data with data from Thomson Reuters Datastream. Our results show that there is a negative relation between CHROs with long company tenure and firms' social performance, whereas CHROs with long role tenure positively relate to firms' social performance. We also investigate the moderating role of CEO prior experience (i.e., HR experience, education, company and role experience) on the effect of CHRO company and role tenure on firms' social performance. Surprisingly, CEO prior experience negatively moderates the relationship between CHRO role tenure and firms' social performance. Overall, this article offers novel implications for the CHRO role and uncovers a distinction between two types of CHROs: CHRO firm dinosaurs versus CHRO role gorillas.
\end{abstract}

Keywords CHRO company tenure $\cdot \mathrm{CHRO}$ role tenure $\cdot$ Firm social performance . $\mathrm{CEO}$ prior experience $\cdot$ Upper echelons research

Nina Engels

haarkoetter@time.rwth-aachen.de

Denise Fischer-Kreer

fischer@time.rwth-aachen.de

Malte Brettel

brettel@time.rwth-aachen.de

1 Innovation and Entrepreneurship Group (WIN)-TIME Research Area, RWTH Aachen

University, Kackertstr. 7, 52072 Aachen, Germany 


\section{Introduction}

In a world of globalization, intercultural work, efficiency pressure, and technology growth, human resources (HR) has reached absolute priority status on many firm agendas (Harvard Business Review 2014). Starting off as a mere administrative function, HR has by now evolved into a key firm-strategic cornerstone (Ferris et al. 1999; Ulrich 1997), and human capital is the top challenge CEOs are facing (Mitchell et al. 2014). Consequently, the leading role of the Chief Human Resource Officer (CHRO) has also undergone substantial changes in the last decades and increased in importance (McKinsey 2020; Wehner et al. 2012). CHROs ensure that employees and human factors remain a first priority for the top management team (TMT), thereby shaping a firm's strategic agenda (Charan et al. 2009). As the leader of the people - the heart of an organization-the CHRO influences employee behavior and improves organizational performance (Wright et al. 2003). It is thus only a matter of time until the CHRO has equal or even more power than the Chief Financial Officer (CFO) (Charan et al. 2009; Donkin 1999; Kelly and Macdonald 2014). Furthermore, the $\mathrm{CHRO}$ role is even sometimes considered a stepping stone towards the Chief Executive Officer (CEO) position (Poba-Nzaou et al. 2020). Despite these developments and even though human capital remains a top challenge for most firms, research offers few insights into the strategic role of CHROs (Abt and KnyphausenAufseß 2017; Poba-Nzaou et al. 2020).

According to upper echelons theory, TMT members significantly impact firm performance outcomes (Menz 2012). Research has analyzed the role of the CEO-the most powerful TMT member-and that of other functional TMT members. Garms and Engelen (2019) emphasize that "a major trend in firms' upper echelons has been to establish functional top management team (TMT) positions (CxOs) to manage critical firm outcomes centrally across business units". Extant studies investigate CFO succession (Geiger and North 2006; Gietzmann et al. 2016; Mian 2001; Zorn 2004), the antecedents and performance consequences of Chief Marketing Officers (CMOs) (Germann et al. 2015; Nath and Mahajan 2008, 2011), or the role of Chief Operating Officers (COOs) for firm performance (Hambrick and Cannella 2004; Marcel 2009). Other works analyze the interface between individual TMT members and the CEO (Heyden et al. 2017; Jiang et al. 2010; Shi et al. 2018).

Scholars highlight that "the role of the head of the HR function [...] has only recently emerged as a senior position worthy of a seat on TMTs" (Smith 2015. p. 7). But HR, as a function, positively influences firm performance (Lin and Shih 2008; Snell and Youndt 1995). Recognizing this, scholars have lately started to explore the antecedents of CHRO presence (Abt and Knyphausen-Aufseß 2017), or the antecedents and performance outcomes of similar CHRO positions such as Chief or Vice President (Smith 2015). The results of such analyses reveal, for instance, that CHROs strongly differ from other TMT members (Cohen 2015) - they typically need an extremely large set of competencies, have a less straightforward career path, and possess a diverse educational backgrounds. Previous research also discusses whether and how CHROs influence their business functions and calls for further investigation (Heyden et al. 2017; Menz 2012; 
Steffensen et al. 2019). However, research has yet to yield insights into CHROs' influence on firm strategic outcomes-which is surprising given CHROs' increasing relevance for company practice (McKinsey 2020).

In upper echelons research, the impact of TMT members is often measured by the performance of their assigned business function (Chung and Kang 2018; Hendricks et al. 2014; Medcof and Lee 2017). In this context, a firm's achievements in the social dimension are a key performance indicator for a CHRO's business function (Scoreboard 2020; Wright et al. 2003). Firm social performance is an aggregated measure and includes a diverse set of function-related HR indicators such as employment quality, diversity and opportunity, or training and development (Lechintan 2017). Extending prior research on upper echelons, it is particularly relevant to investigate the experience of CHROs since they need to possess different competencies than other TMT members (Cohen 2015). We argue that CHROs' firm and role tenure in particular help explain variances in firms' social performance for the following reasons: executives, above all those with relatively long firm tenure, often tend to resist major strategic reorientations-they are inclined to rely on existing practices, activities, and networks and are thus locked in a certain path dependency (Hambrick and Fukutomi 1991; Miller 1991; Wiersema and Bantel 1992). Increasing role tenure, in contrast, allows CHROs to identify with the strategic arrangements they have initiated (Grühn et al. 2017). We consequently propose a negative relationship between CHRO company tenure and firm social performance, but a positive relationship between CHRO role tenure and firm social performance.

It is important contextualize these links. A CHRO's strategic decision-making does not occur in a vacuum but depends on joint decision processes with a firm's most important decider-the CEO (Finkelstein and Boyd 1998; Quigley and Hambrick 2015). Assuming that CEOs moderate the relationship between CHRO tenure and firm social performance, we focus our theorizing on CEO prior experience. Research shows that CEOs with diverse work experience own the cognitive breadth to develop dynamic and unique strategies (Crossland et al. 2014). Such CEOs also display creativity and versatility in problem-solving, which might help CHROs drive firm social performance (George and Zhou 2001; Wang et al. 2016). We assess CEOs' prior experience as their accumulated wealth of experience gained during education, tenure in the current company, tenure as a CEO (role tenure), and years of HR experience. We posit that CEOs' prior experience positively moderates the relationship between $\mathrm{CHRO}$ tenure (i.e., company and role tenure) and firm social performance. Overall, this study aims to investigate the following research questions: (1) How does a CHRO's company tenure influence the social performance of a firm? (2) How does a CHRO's role tenure influence the social performance of a firm? (3) How does the CEO's prior experience affect these relationships?

To test our theorizing, we composed a unique longitudinal dataset with information on 13,130 firm-year and executive observations from 2005 to 2017 of U.S. firms listed in the Standard \& Poor's (S\&P) 500 Index. The regression analyses results confirm our theory that CHROs' role tenure is positively associated with firm social performance, whereas CHRO company tenure is negatively associated with firm social performance. Surprisingly, our findings further suggest that CEO prior 
experience negatively moderates the link between $\mathrm{CHRO}$ role tenure and firm social performance.

This article offers several contributions to theory, of which we now outline the two most valuable ones: first, with our detailed and profound understanding of CHROs' increasingly pivotal role, we extend current research on upper echelons. Using a unique dataset, we derive empirical insights into CHROs and their impact on firms' social performance. Most importantly, our findings reveal a clear typification of CHROs and indicate two distinct types: the CHRO role gorilla and the CHRO firm dinosaur. A CHRO role gorilla has accumulated a wealth of knowledge related to this role and has often gained prior CHRO experience in other companies. Our results show that this type of $\mathrm{CHRO}$ achieves higher firm social performance. CHRO firm dinosaurs, in contrast, have spent most of their career within the company in which they hold their present $\mathrm{CHRO}$ position. Even though they know the company inside-out, our findings indicate that company tenure has a negative effect on firm social performance. Second, this study highlights the moderating role of CEOs' prior experience regarding the link between CHRO and firm social performance. Specifically, we measure how experienced CEOs (i.e., HR experience, education, company and role experience) support CHROs in driving firm social performance. Surprisingly, an experienced CEO weakens the positive effect of CHROs' role tenure on firm social performance. Overall, this study enables academics and practitioners to appreciate the $\mathrm{CHRO}$ tenure characteristics that can promote or hinder their firms' social performance.

\section{Theoretical framework and hypotheses}

\subsection{The CHRO as a valuable part of the TMT}

Upper echelons theory is one of the most established and acknowledged theories within research on TMTs (Menz 2012). It originates from strategic decision-making in the context of corporate firms (Child 1972). Upper echelons perspective states that the observable characteristics of executives shape their cognitive biases and values, which in turn influence strategic choices and subsequent organizational outcomes (Carpenter et al. 2004; Hambrick and Mason 1984). It is still a growing research stream. In the last decade, more than 140 articles were published in major journals on upper echelons and TMTs (Bromiley and Rau 2016). Thus, upper echelons research has become one of the most prominent and influential areas in the management field (Neely et al. 2020). Since the 1990s, upper echelons research deepens the understanding of TMT compositions (Carpenter et al. 2004) and the effects of a CEO (A. Chatterjee and Hambrick 2007). One of the latest developments of upper echelons perspective is analyzing individual functional TMT members such as the CFO (Geiger and North 2006; Zorn 2004), the COO (Hambrick and Cannella 2004; Marcel 2009; Zhang 2006), or the CMO (Nath and Mahajan 2008; Wiedeck and Engelen 2018). As already mentioned, the number of firms with a CHRO increase rapidly to give HR-related topics a voice in the firms' upper echelons and to ensure that these topics receive sufficient resources (Menz 2012). So far, upper echelons 
theory is limited in providing insights into a single executive's role at the upper echelons level (Garms and Engelen 2019). Indeed, as Menz (2012) argues, the literature on functional $\mathrm{CxOs}$ ignores multiple functional responsibilities, such as the CHRO, in favor of other functional executives (e.g., COOs, CFOs). This is surprising given that the existence of functional $\mathrm{CxOs}$ who represent only one function are likely to influence strategic decision-making, resource commitments, and attentions in TMTs.

In essence, the upper echelons perspective is a theory of information processing (Cho and Hambrick 2006; Van Doorn et al. 2017). TMTs are seen as informationprocessing groups who overcome information barriers to ensure decision-making effectiveness (Schepker et al. 2018). By understanding TMTs as information-processing instruments, research on upper echelons can examine the role contingencies play in facilitating or hindering information processing. The information-processing view is grounded in the concept of bounded rationality. It presumes that executives have to deal with too many pieces of information and therefore rely on biases such as their experiences and preferences (Cyert and March 1963). In line with this notion, researchers have explored the influence of several TMT characteristics on organizational outcomes (Bromiley and Rau 2016): for instance, the effect of multiple characteristics such as experience (Angwin et al. 2009; Cannella et al. 2008; Crossland et al. 2014), tenure (Chung and Kang 2018), age (Bantel and Jackson 1989), or gender (Klenke 2003; Velte 2016). However, there are still unsolved questions in upper echelons research, and scholars call for further studies of individual functional TMT members to better understand their impact on particular function-specific outcomes (Menz 2012).

Given the immense practical relevance and strong development of the CHRO role (Abt and Knyphausen-Aufseß 2017), it is surprising that research on the effect of the CHRO is still in its infancy (Steffensen et al. 2019). Many studies explore human resource management (e.g., Backes-Gellner et al. 2016; Flickinger et al. 2013), but there is no examination of managers' roles (Steffensen et al. 2019). Even though several reviews and calls for future research exist (Becker and Huselid 2006; Posthuma et al. 2013; Steffensen et al. 2019; Su et al. 2018), findings on CHRO impact and characteristics are limited. CHROs drive and shape companies' HR content, HR processes, and HR outcomes (Steffensen et al. 2019). They are called firms' leaders of human capital, trusted advisors and coaches, enterprise change leaders, drivers of culture and purpose, and creators of talent strategy (Ishrak and Surface 2019). The rare studies that do exist on CHROs aim to explain the antecedents of CHRO presence in a company. Abt and Knyphausen-Aufseß (2017) showed that unionized workforce, outsider CEOs, institutionalization within the industry and the firm positively influence CHRO presence. Other studies focus on the CHRO level (the hierarchical title of the position in a company) by examining that international complexity negatively influences this level (Smith 2015). Scholars thus see the need to investigate the function-related outcomes of a CHRO: "Another area of future study is the impact of the CHRO role on firm decisions, functional outcomes, firm strategy, or on the nature of the TMT. While many firms are elevating the role of the HR leader, the outcome and impact of this role is so far unclear" (Smith 2015, p. 54).

According to actual CHROs, the HR role in the TMT differs from other HR positions in the organization reporting to the $\mathrm{CHRO}$ as there is no preparation 
for the role: a person needs to be in the role to learn it (Wright et al. 2011). This study hence aims to understand CHROs' previous experience better. To refine our comprehension of the $\mathrm{CHRO}$ role, we highlight the crucial aspect of tenure. Multiple studies analyze the career paths of TMT members, for example, the CFO (Chahyadi and Abusalim 2011; Gray 2000; Murphy 2014). However, a CHRO's typical career path so far remains unclear and differs from that of other TMT members. The journey towards the $\mathrm{CHRO}$ position is less straightforward than others (Chiappetta 2019; Workforce Partnership Staff 2019). Therefore, this study investigates the variable tenure for two reasons. First, it is an indicator of one of the longest experiences in executives' career path (Hambrick and Fukutomi 1991). Second, tenure reflects "the accumulation of specialized and organizationally relevant knowledge" (Tanikawa and Jung 2016, p. 456). Extant research differentiates between company and role tenure: company tenure is the number of years a person has worked in a company (Schwenk 1993); role tenure is defined as the sum of years a person has worked as CHRO before (Hunter and Thatcher 2007).

In this article, we position a firm's social performance as the legitimate outcome variable for assessing the role of a CHRO. Firm social performance is defined as an aggregated measure of employment quality, diversity and opportunity, training and development, health and safety, human rights, community, and product responsibility (Reuters 2015). Literature often reflects these outcomes as key performance indicators to evaluate CHRO performance (Becker et al. 2001; Jessee 2020; Lechintan 2017; Wright et al. 2003). For instance, Abt and Knyphausen-Aufse 3 analyzed 24 press releases and $17 \mathrm{CHRO}$ job descriptions. They summarized the tasks and responsibilities of a CHRO which are reflected in the subdimensions of a firm's social performance. Further, the authors' description of the $\mathrm{CHRO}$ role and its responsibilities aligns with the broader, emerging literature on functional CxOs (e.g., Menz 2012). Therefore, we see firm social performance as the variable suited best to assess the performance of CHROs and their function-specific outcome. Figure 1 depicts our research model and illustrates how CHRO company and role tenure relate to firms' social performance. In the following, we derive the four hypotheses of this study.

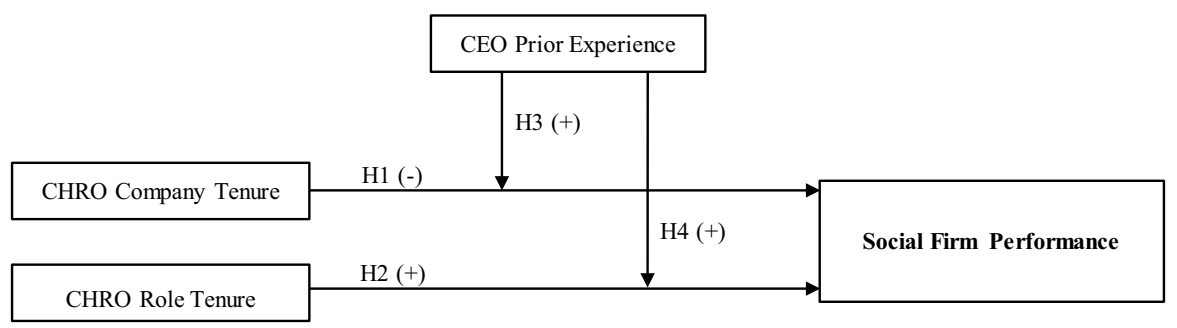

Fig. 1 Research model 


\subsection{The direct effect of CHROs' company tenure on firm social performance}

Drawing on information-processing theory, we consider CHROs as informationprocessing actors. The CHRO is a crucial channel for TMTs to process HR-related information. Prior experiences have been shown to influence how executives process information and data, which ultimately explains differences in decision-making (Crossland et al. 2014). We now concentrate on CHROs' experience gained during company tenure.

Arguing from a more optimistic view, overall job performance might improve with increasing knowledge of a company (Weisberg 1996). Moreover, employees with long company tenure can rely on established ties with current stakeholders such as board members, managers, or executives (Hambrick et al. 1993; Kor 2003). These network ties lead to a perceived safeguard, reliability, stability, and predictability that benefit existing activities of the firm by reducing transaction costs and facilitating interactions within established groups (Flood et al. 1997; Heyden et al. 2017; Michel and Hambrick 1992). However, long company tenure also has detrimental effects, which is especially important regarding CHROs' role in firm social performance.

Extant research reveals that, with increasing company tenure, employees tend to become more bored and less motivated at work, prefer the status quo over change, and show signs of inertia (Ng and Feldman 2013). This is in line with the information-processing view, which posits that executives have to deal with many pieces of information and hence rely on biases such as their experiences and preferences (Cyert and March 1963). Longer company tenure leads to a reduced effort in gathering additional information and limited engagement in rethinking existing activities and structures (Boeker and Wiltbank 2005). Based on this, CHROs with longer tenure would put less effort in questioning current recruiting strategies, training systems, retention programs, and reward systems. Similar to regular employees, they tend to hold on to their norms and have a status quo bias (Samuelson and Zeckhauser 1988) - a phenomenon that increases along with firm tenure. It might be especially difficult for CHROs with long firm tenures to seek objective perspectives on their firms' social performance measures or to benchmark them against peers. Moreover, executives with long company tenure tend to become blind to organizational deficiencies and have issues prioritizing company decisions and arrive at adequate conclusions (Hambrick et al. 1993). Overall, CHROs with long tenure in a single company might be less inclined to gather and process information from diverse and company-external sources. Hence, CHROs' company tenure might narrow their capacity to process information effectively, which has detrimental outcomes for firm social performance. Thus, we hypothesize:

H1: CHRO company tenure is negatively related to the social performance of a firm.

\subsection{The direct effect of $\mathrm{CHRO}$ role tenure on firm social performance}

The effect of CHRO role tenure on firm social performance differs from the direct effect of CHRO company tenure. The information-processing perspective allows us to better understand how role tenure shapes CHROs' decision-making rationale. First, it is 
particularly important to examine the experience gathered in CHRO roles because this reflects CHROs' information-processing capacity (Schepker et al. 2018). CHROs with more role-specific experience-possibly gathered in different firms - can process HRrelated information from distinctive angles and against new environments and have a broader cognitive frame, resulting in creative solutions (Crossland et al. 2014). Second, CHROs with longer role tenure already own an HR toolkit they can readily deploy (e.g., how to create an HR plan, convince the TMT). They can build on existing connections of information and tend to apply trusted formulas with proven effectiveness and validity (Hambrick and Fukutomi 1991; Miller and Shamsie 2001). With increasing role tenure, CHROs can develop more concrete beliefs about proper norms of behavior and causeeffect linkages, which are a result of prior feedback on social performance in other companies (Finkelstein and Hambrick 1990).

Third, experienced CHROs can evaluate their applied HR toolkit based on the feedback they receive from employees or other TMT members. Individuals tend to repeat practices that have led to success in the past (Miller 1994)—in our context, to enhanced firm social performance. Successful individuals attribute their achievements to their earlier behavioral patterns and aim to retain these patterns (Crossland et al. 2014). Fourth, the information-processing perspective on the beneficial impact of CHRO role tenure on firm social performance is also supported by arguments underlying the theoretical concept of vicarious learning. According to this concept, executives with more experience in a specific role can learn new role-related tasks more quickly if these are similar to previous ones (Gioia and Manz 1985). CHRO experiences gained within role-specific tenures might result in a company-independent and essential experiential learning curve. A tenured CHRO might display enhanced logical thought processes that facilitate decision-making grounded in a broader and less firm-dependent perspective (Prahalad and Bettis 1986). Such experiences and decision logics help CHROs heighten their role performance, which is especially important as CHRO job descriptions are still not fully determined and the role still undergoes many changes (Wright et al. 2011). Overall, we expect CHRO role tenure to foster firm social performance and hypothesize:

\section{H2: CHRO role tenure is positively related to the social performance of a firm.}

\subsection{The moderating role of CEO prior experience}

The CEO - the most powerful individual in a firm-has attracted the interest of researchers for a long time. Arguing from upper echelons perspective, CEOs play a central and important leadership role in a firm and are generally in charge of setting its strategic course (Georgakakis et al. 2019). CHROs cannot promote the social performance of a company on their own: they rely on the commitment and strategic support of their CEO (Georgakakis et al. 2019). Prior studies on CEOs show that specific CEO characteristics—such as demographics (Barker and Mueller 2002), tenure (Zona 2016), or career horizon (Cho and Kim 2017) — are associated with a firm's strategic performance outcomes. CEOs and other top executives are the main drivers of corporate activities, and their decisions are based on own experiences, values, and personalities (Hambrick 2007; Hambrick and Mason 1984). Scholars 
have started to focus on CEO backgrounds to understand how different career paths influence CEO decision-making and, ultimately, affect organizational outcomes (Crossland et al. 2014; Koyuncu et al. 2016). Examining diverse experiences gathered during CEO careers is particularly important because such experiences equip CEOs with broad cognitive frames needed to process information from a wide variety of sources (Crossland et al. 2014). Drawing on the information-processing and upper echelons perspectives (Hambrick 2007), we argue that CEOs with more prior experience will support CHROs in driving a firm's social performance.

A CHRO primarily promotes and shapes firm social performance, while the CEO supports judgments and devises suitable ways to align firm capabilities with environmental demands (Carpenter and Sanders 2004; Hambrick and Mason 1984). Hence, the CHRO would benefit from a CEO with pronounced information-processing capacities. We focus on CEOs and CHROs as information-processing actors because this allows us to understand their decision-making rationale (Schepker et al. 2018). The information-processing view draws on the concept of bounded rationality. It presumes that executives have to deal with too many pieces of information and therefore rely on biases such as experiences and preferences (Cyert and March 1963). It is thus particularly important to examine the experiences gathered during CEO careers because they reflect the respective information-processing capacity. A CEO's strong information-processing capacity promotes the relationship between CHRO and firm social performance. Following extant research on CEOs' prior experience (Crossland et al. 2014; Hamori and Koyuncu 2015; Koyuncu et al. 2016), we argue that the following experiences in particular enhance CEOs' information-processing capacity: first, the education of CEOs represents a main selection criterion because it indicates their competency to handle the logical and intellectual complexity of the job (Grimm and Smith 1991). Second, CEO company and role tenure have been shown to be an essential antecedent for CEO performance (Simsek 2007; Weng and Lin 2014). Third, CEOs' prior HR experience might be especially beneficial for the link between CHRO and firm social performance. CEOs with prior $\mathrm{HR}$ experience are familiar with HR tools, frameworks, and knowledge, which is advantageous for CHROs as such CEOs might be able to offer more guidance and require fewer explanations.

The information-processing perspective shows that the more experienced CEOs are, the better is the advice they can offer. Thus, a CEO's prior experience fosters exchange mechanisms between $\mathrm{CHRO}$ and $\mathrm{CEO}$, which are essential for ultimately driving firm social performance. We hypothesize:

H3: CEOs' prior experience weakens the negative relationship between CHROs' company tenure and the social performance of a firm.

H4: CEOs' prior experience strengthens the positive relationship between CHROs' role tenure and the social performance of a firm. 


\section{Methodology}

\subsection{Data and sample}

For this study, we collected a unique longitudinal dataset consisting of multiple input factors from secondary data sources. Our sample contains observations from 2005 to 2017 of U.S. firms listed in the Standard \& Poor's (S\&P) 500 Index. The sample period covers a period of more than 10 years to allow a comprehensive longitudinal investigation and to ensure that the data allow reliable predictions of TMT impact (Chatterjee and Hambrick 2007). This is also in line with recent longitudinal research on functional TMT members such as the Chief Sustainability Officer (Fu et al. 2020).

Following prior upper echelons research on TMTs in large firms (Cannella et al. 2008; Menz and Scheef 2014; Nath and Mahajan 2008), we operationalize the TMT as the executive officers listed by firms in their annual Form 10-Ks or proxy statements filed with the Securities Exchange Commission. This represents a more comprehensive TMT definition than the also widely used operationalization based on S\&P Capital IQ's ExecuComp database (Messersmith et al. 2014; Steinbach et al. 2016), which typically only lists the five highest-paid executives. We manually collected data on the firms' TMT structure from the Form 10-Ks and proxy statements. To ensure comparability, we focus on functional TMT members with direct reporting lines to the CEO - as done in earlier TMT research (Guadalupe et al. 2012; Menz 2012). If TMT member roles were unclear, we complemented the data with information from company websites and professional profiles (e.g., Bloomberg, LinkedIn).

Our dependent variable, firm social performance, is part of the environmental, social, and governmental (ESG) performance. We obtained firms' ESG performance in the same period from Thomson Reuters Datastream (category ESG-Asset4). The ESG database comprises data from annual reports, company websites, stock exchange filings, CSR reports, and news sources. The Asset4 data are updated biweekly. For this study, we retrieved the social performance data for the period under review in January 2019. The overall ESG score is calculated by equally weighting all underlying data points, z-scoring, and comparing them with all other firms' data points to obtain a relative measure of performance, expressed as a percentage ranging from 0 to 100 (Reuters 2015). We gathered all other firm-related financial information from the COMPUSTAT database.

Our total sample initially (i.e., before removing unusable data; see below) consisted of 753 companies, 6130 firm-year observations, and 13,670 TMT executives, yielding 54,971 firm-year and executive observations.

The total dataset underlines the growing importance assigned to the CHRO role. With a growth rate of $13 \%$ from 2005 to 2015, the CHRO role showed the secondhighest increase after the Chief Sustainability Officer role (18\% growth rate). Overall, about $54 \%$ of the prevalence of firm-years have a CHRO in their TMT; in 2005, fewer than $50 \%$ of companies had a CHRO, which is in line with prior research on CHRO presence (Abt and Knyphausen-Aufseß 2017). Given this study's purpose, our final dataset only includes companies with CHRO. Further, we only observe firms with sufficient information on $\mathrm{CHRO}$ tenure and $\mathrm{CEO}$ prior experience to 
secure reliable measures. After merging all datasets and removing observations due to missing or incomplete data, the final sample consists of 283 companies with 1944 firm-year observations from 2005 to 2017.

\subsection{Measures-dependent variable}

\subsubsection{Firm social performance}

To assess the impact of CHROs on firms' social performance, we rely on the Thomson Reuters social performance scores which is already a well-established variable in current research (e.g., Veltri et al. 2021). Social performance is part of the ESG performance and is also measured from 0 to 100, where 100 is the highest score. Social performance is an aggregated measure and comprises seven subdimensions: (1) Customer Product Responsibility, (2) Society Community, (3) Society Human Rights, (4) Workforce Diversity and Opportunity, (5) Workforce Employment Quality, (6) Workforce Health and Safety, and (7) Workforce Training and Development. Table 1 provides an overview of mean scores per industry for our social performance score and the respective seven sub-dimensions.

\subsection{Measures-independent variables}

\subsubsection{CHRO's company tenure}

We measure CHRO's prior experience in the firm or "company tenure" as the number of years of employment in the firm of TMT members before appointment as CHRO (Finkelstein and Hambrick 1990; Nath and Mahajan 2017).

\subsubsection{CHRO's role tenure}

We measure CHRO's job tenure in the role as the sum of years the person worked as a CHRO before similar to other scholars (Hunter and Thatcher 2007).

\subsection{Measures-moderating variable}

\subsubsection{CEO prior experience}

We measure CEO prior experience as the sum of the years of education, of tenure in the current company, of tenure as a CEO (role tenure), and of HR experience (Crossland et al. 2014; Hamori and Koyuncu 2015; Koyuncu et al. 2016). We measure HR experience if a person worked in an HR-related function before. All information stems from Bloomberg and LinkedIn. 


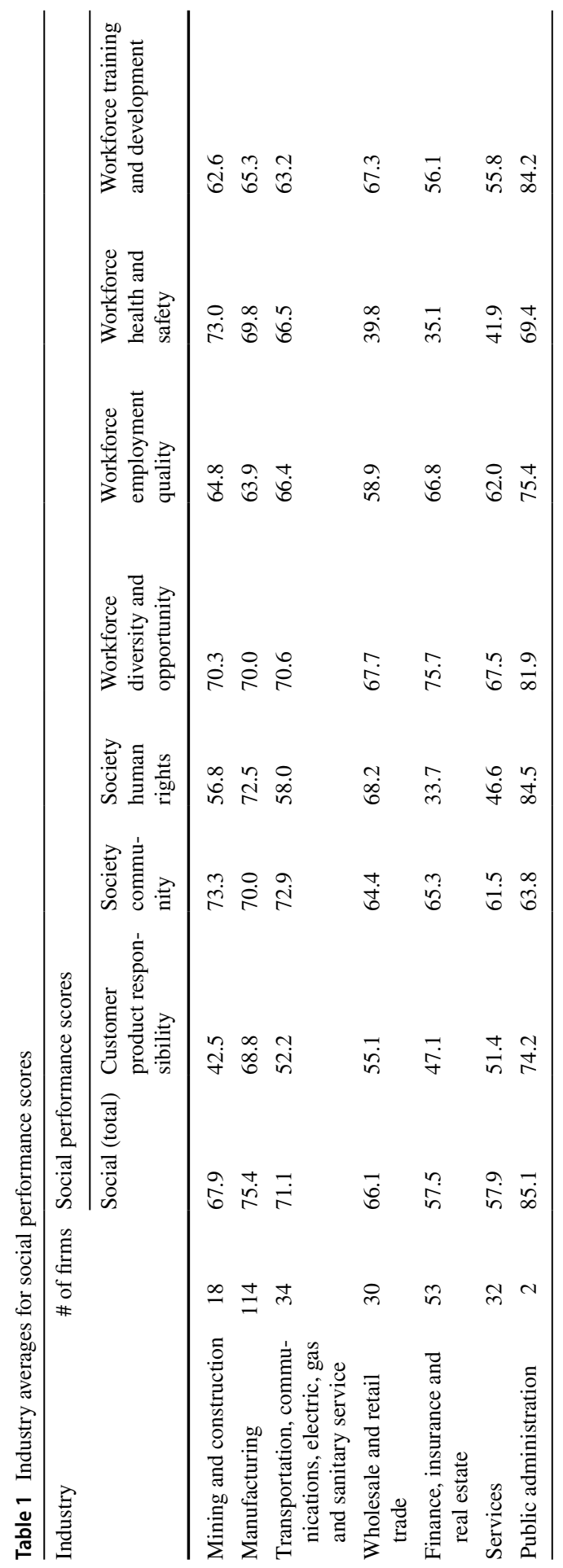




\subsection{Measures-control variables}

We include control variables on firm, TMT, and CEO levels to reduce variance that is not directly associated with our explanatory variables. On the firm level, we follow existing research and include firm age and size as well as sales. Larger and older firms have more resources to allocate, less rotation, and more TMT positions (Campion et al. 1994). On the TMT level, we control for TMT size because it might influence firm performance (Hoffman et al. 1887). We also control for CHRO age as older CHROs might have longer company and role tenures than younger ones. Following prior research (Chung and Kang 2018; Zhang 2006), we also control for CEO characteristics since CEOs have the highest position and influence in a company. We thus control for CEO age, CEO duality (i.e., CEO also serves as board chair) (Krause et al. 2014), and structural CEO power measured as the title ranks using the established coding by Garms and Engelen (2019).

\subsection{Analytical method}

To test our research questions, we analyze cross-sectional time-series data, which reduces the degree of multicollinearity, increases the generalizability of results over time, and improves the stability of estimation parameters (Kumar et al. 2011). Following comparable research (Rivas 2012), we use the OLS regression since our dependent variable, firm social performance, is normally distributed with skewness of -0.76 . Furthermore, the Hausman (1978) test (null hypothesis: there is no difference between random and fixed effects estimates) supports a firm fixed-effects model $\left(\chi^{2}(19)=52.15, p<0.0001\right)$. This is consistent with other research since fixed-effects models are preferred in panel data analyses (Greene 2003). We use robust standard errors to control for heteroscedasticity (White 1980). All variables in our analysis (except for dummy variables) are standardized to improve interpretability and reduce potential multicollinearity (Aiken and West 1991).

\section{Results}

\subsection{Descriptive statistics}

Table 2 summarizes the descriptive statistics and correlations for all variables. Our independent variables (CHRO role and company tenure) are positively correlated with each other with a correlation of 0.31 ; one of our independent variables (CHRO role tenure) is positively correlated with one of our control variables (CHRO age) with a correlation of 0.40 . Further, our moderating variable (CEO prior experience) and one of our control variables (CEO age) are positively correlated with 0.33 . Lastly, firm age and firm social performance are positively correlated with a correlation of 0.41 . To explore the risk of multicollinearity sufficiently, we follow suggestions from scholars (Kalnins 2018). To investigate 
potential issues with multicollinearity, we calculate variance inflation factors (VIFs) and the condition index for all variables. The average VIF value is 1.17 , well below the recommended cutoff of 10. The highest VIF is 1.31, and tolerance is also below 1.0. These tests indicate that multicollinearity does not bias our findings (Chatterjee and Hadi 2000; Mansfield and Helms 1982). Furthermore, we run the same regression with independent and control variables lagged by 1 year, which yielded similar results, to reduce the risk of reverse causality and simultaneous causality.

As we can see in our dataset, both tenures differ significantly from each other. The average CHRO role tenure in our sample is 4.0 years, with a standard deviation of 3.7. The average company tenure of CHROs in our sample is 11.1 years, with a standard deviation of 9.5 years. One reason for this difference might be that the career path to $\mathrm{CHRO}$ is less straightforward than that towards other executive roles, and new CHROs are often selected from a firm's own HR department (Wright et al. 2011).

\subsection{Results}

Table 3 presents the results for all hypotheses. Proceeding to the multivariate analysis, we approach model specification in a stepwise procedure. First, we run a model only with control variables (Model 1). Second, we introduce the independent variables corresponding to Hypotheses 1 and 2 (Model 2). Third, we run the base model with Hypothesis 3 (Model 3). Afterward, we include Hypothesis 4 instead of Hypothesis 3 (Model 4). Finally, we establish the full model, including the moderating effect of both independent variables (Model 5). As the stepwise approach reveals, there is no indication of unstable estimates across models.

We find support for our first hypothesis that CHRO company tenure is negatively related to the social performance of a firm (Model 2: $\beta=-3.127 ; \mathrm{p}<0.001$; Model 5: $\beta=-3.115 ; \mathrm{p}<0.001)$. Furthermore, the results confirm Hypothesis 2: CHRO role tenure is positively associated with firm social performance (Model 2: $\beta=1.953 ; \mathrm{p}<0.01$; Model 5: $\beta=2.102 ; \mathrm{p}<0.01)$. However, we cannot confirm Hypothesis 3 since the significance level is insufficient $(\mathrm{p}=0.3)$ based on Model 3. In our Hypothesis 4, we propose that CEO prior experience strengthens the positive relationship between $\mathrm{CHRO}$ role tenure and firm social performance. However, the results indicate that CEOs' prior experience weakens the positive relationship between CHRO role tenure and firm social performance significantly (Model 4: $\beta=$ -1.294 ; $\mathrm{p}<0.01$; Model $5: \beta=-1.347 ; \mathrm{p}<0.01$ ). Figure 2 illustrates this moderating effect. The slopes are significantly different from zero for low and high levels of CEO prior experience $(\mathrm{p}<0.01)$.

To confirm that our variables improve the explanatory power of the model in a statistically meaningful manner, we also run the same analysis with the generalized estimating equations (GEE) model (Ballinger 2004). In the GEE model, we include one-digit SIC dummy variables to account for industry-fixed effects. We specify the GEE model with an identity link function, a Gaussian family, and an exchangeable error correlation structure for a better robustness check (Krause et al. 2015). 


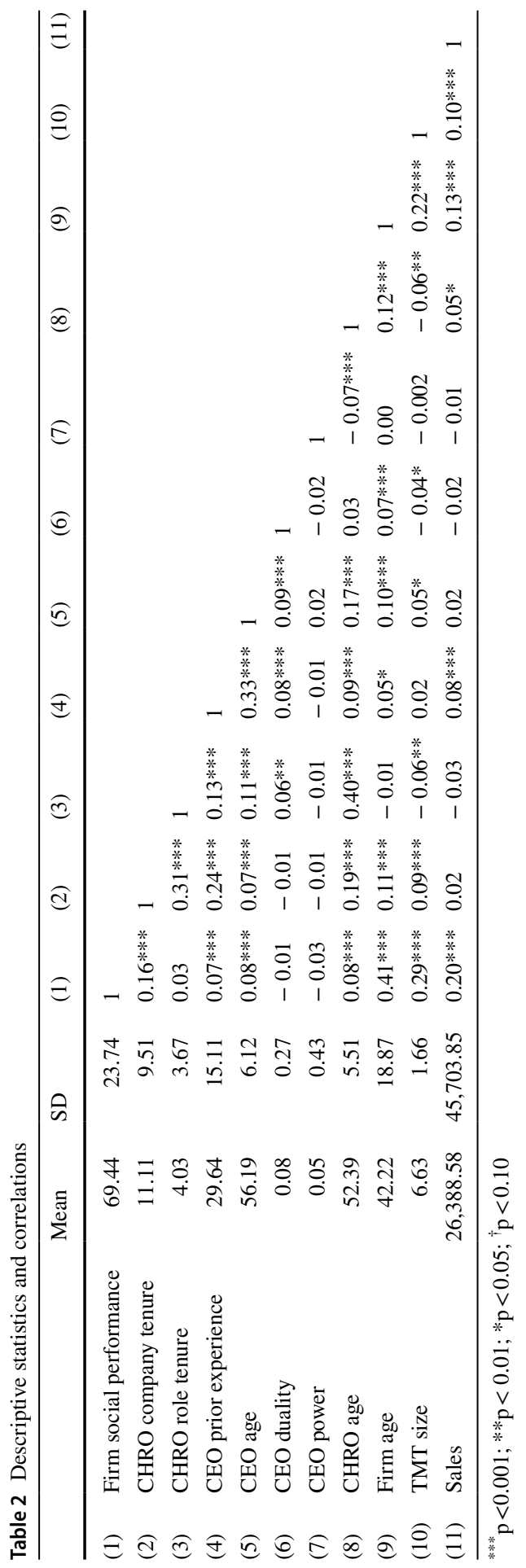




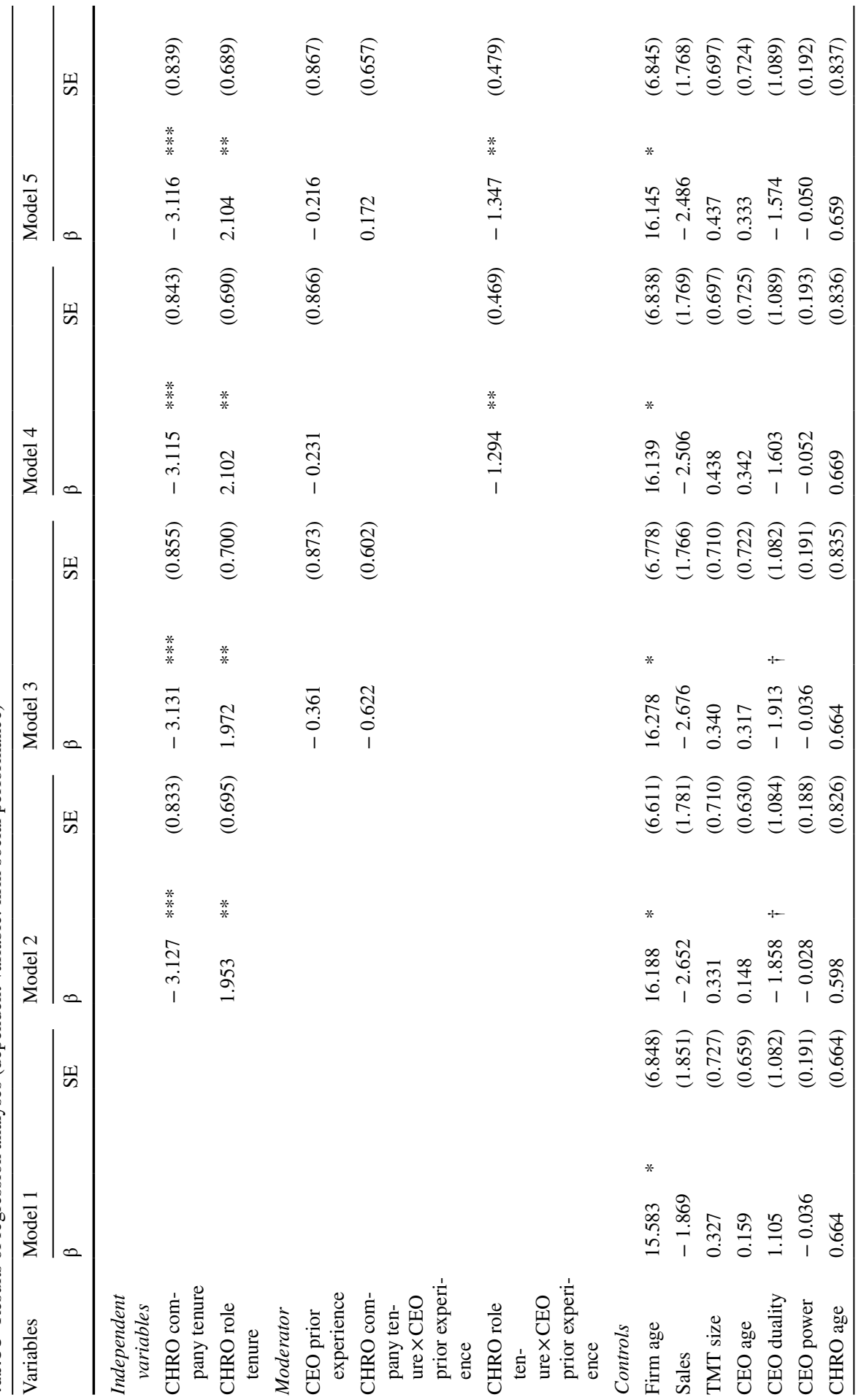




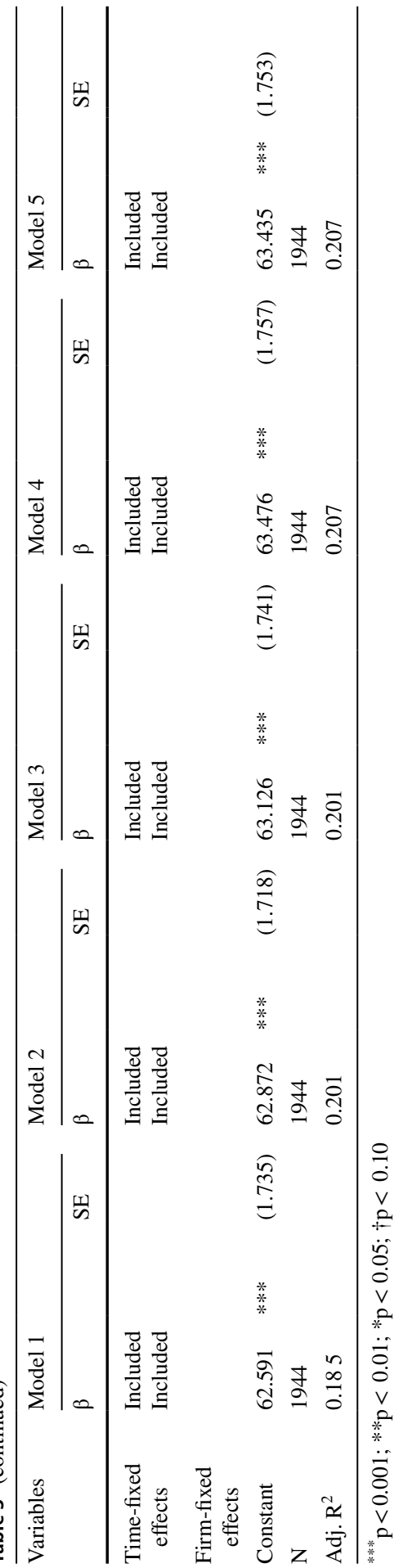


Furthermore, we get similar results by lagging all variables by 1 year. All three models lead to similar results, demonstrating that our results are robust across different modeling techniques.

\section{Discussion}

The aim of this study is to provide novel insights into the role of CHROs, their career paths, and their impact on a firm's social performance. Furthermore, we investigate the moderating effect of CEOs' prior experience. Overall, we find evidence for our first two hypotheses that explain which experiences might help CHROs drive firms' social performance. Our results confirm that CHROs' role tenure positively relates to firm social performance, whereas CHROs' company tenure negatively relates to it. Surprisingly, we found a negative moderating effect of CEO prior experience on the relationship between CHRO role tenure and firm social performance. These findings have several theoretical and practical contributions.

\subsection{Theoretical contributions}

This study has three major contributions to extant research and theory. First, several implications result from the findings of the base model, including $\mathrm{H} 1$ and $\mathrm{H} 2$. This study is a major milestone for upper echelons literature, as it offers novel insights into the role of a CHRO. Due to its increasing practical and academic relevance (Harvard Business Review 2014; Paauwe and Boselie 2005), it was long overdue to better understand CHROs and their career paths and their influence on firms' social performance. Earlier upper echelons literature focuses strongly on other TMT members (Menz and Scheef 2014; Wiedeck and Engelen 2018; Zorn 2004) and fails to deepen knowledge on the CHRO. This study starts to close this gap in extant research. Our study offers insights into the CHRO tenure's effect on

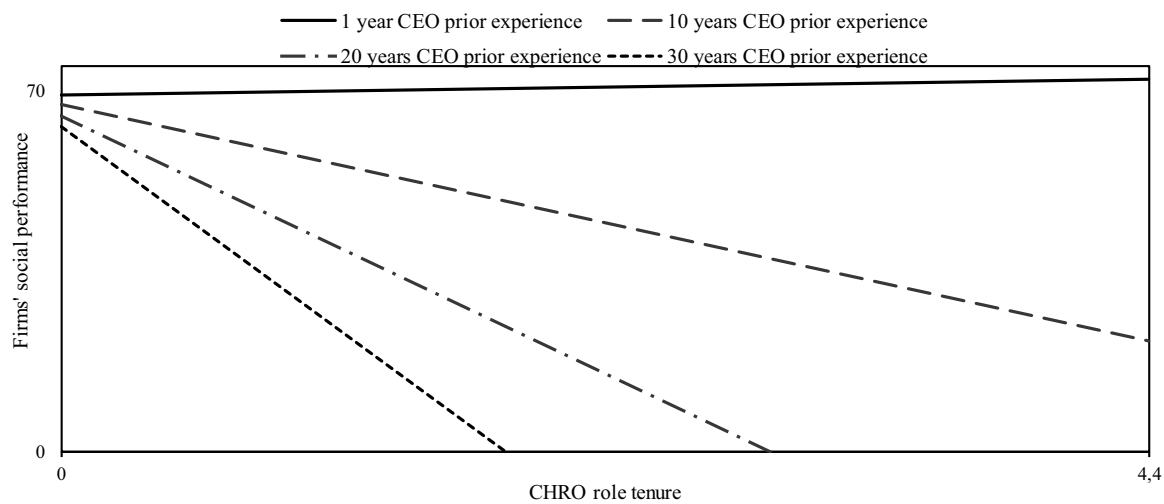

Fig. 2 The moderating effect of CEO prior experience on the relationship between CHRO role tenure and firms' social performance 
the TMT's strategic decision-making for a firm's social performance. Thereby, this study enriches upper echelons theory by showing that CHROs, with their experiences gathered along company and role tenure, shape a company's social performance. By revealing that CHROs' company tenure negatively influences firm social performance while role tenure affects it positively, this study offers support for both the positive and the negative underlying mechanisms of tenure, which is in line with information-processing theory. Indeed, our results suggest that future research should differentiate carefully between executives' company and role tenure. We conclude that our study paves the way for future studies on functional $\mathrm{CxOs}$ and follow Fu et al. (2020) who emphasize that "learning more about the role of senior executives in charge of specific functions can be fruitful for upper echelons theory".

Second, interpreting the findings of our base model leads to an intriguing finding for CHRO literature. Our results indicate that two different types of CHROs exist: $\mathrm{CHRO}$ firm dinosaurs and $\mathrm{CHRO}$ role gorillas. The $\mathrm{CHRO}$ firm dinosaur can be described as an individual with long company tenure. Company-grown CHROs know the majority of people within the firm, are well integrated and familiar with firm history, and promote the culture of the firm in which they were appointed CHROs. Some CHRO dinosaurs have worked in the same company for several decades until finally becoming CHRO. An example from practice is Karen Parkin, who worked in different departments (sales, business development, logistics and supply chain, and HR) at adidas for 20 years before being appointed CHRO in 2014. Our results indicate that an organization with a $\mathrm{CHRO}$ firm dinosaur shows poorer social performance. In contrast, CHRO role gorillas can be described as individuals who have held CHRO positions for a long time, most of them even in different firms. They are experienced in the job and know their tools quite well. Like a silverback among gorillas, a CHRO with long role tenure is able to take care of the company's social responsibility and the well-being of its employees, all of which has a positive impact on the firm's social performance. Real-life examples for CHRO role gorillas are Martin Seiler or Victoria Berger-Gross, the former is CHRO at Deutsche Bahn AG and the latter was CHRO at Tiffany \& Co. Both have been CHROs in multiple companies. In detail, our analyses show that long role tenure helps CHROs achieve higher firm social performance. Overall, our proposed typification is a new discovery in CHRO literature and contributes to recent research on executive typologies (e.g., Chen et al. 2020).

Third, important implications result from the moderating effect of CEO prior experience. We add to the literature on the exchange mechanisms between CEOs and their functional TMT members (Cao et al. 2010; Chi et al. 2010; Heyden et al. 2017; Stoker et al. 2012). Surprisingly, our results reveal a negative effect of CEO prior experience on the relationship between CHRO role tenure and firms' social performance. One might speculate that the negative moderating effect of CEOs' prior experience is a result of their strong commitment to the status quo (McClelland et al. 2010), which makes it hard for CHROs to drive firms' social performance. For instance, prior research emphasizes the negative effects of CEO prior experience as "negative learning effects, cognitive entrenchment, and the hardening of skills" (Bragaw and Misangyi 2017, p. 246). Additionally, earlier works (e.g., Hambrick and Fukutomi 1991) show that long-tenured CEOs act based on their own paradigm, 
are committed to and avoid information that disconfirms their paradigm, become less responsive to task stimuli, or even ignore calls for strategic change. Further, CEOs with prior HR experience might want to discuss more, contribute their opinion more, or want more say in HR-related tasks (Miner et al. 2011). In our case, the CEO wants to participate more in shaping the HR agenda and to interact more with the CHRO. This involvement might hamper CHROs in driving firms' social performance. One might also speculate that the negative moderating effect of CEO prior experience stems from the additional information-processing requirements that especially high-experienced CEOs put on CHROs. Overall, our results suggest that the interaction mechanisms between highly experienced CEOs and CHROs are not fruitful for firms striving to enhance social performance.

\subsection{Managerial contributions}

This research also offers various implications for practitioners. First, this study confirms the increasing importance of the CHRO role within TMTs. This enhanced understanding of CHROs' impact helps CEOs and their boards of directors to decide on when best to hire a CHRO. This study offers large companies guidance on why they should integrate this role within their TMT if they want to promote their social performance, and what kind of CHRO they need. Our results indicate that a CHRO with low company tenure and long role tenure is advantageous. For CHROs, our insights might be helpful in their career paths. We want to encourage growing CHROs to change companies and expand their knowledge. Lastly, this study gives guidance to CEOs in their daily collaboration with CHROs: our results suggest granting CHROs with long role tenure freedom to operate-even if CEOs themselves are highly experienced in HR or with the company.

\subsection{Limitations and avenues for future research}

Our study is subject to certain restrictions that also open up promising avenues for future research. First, we hope that this research provides the groundwork for many follow-up studies examining the promising role of CHROs. This role can be approached from several angles to understand it in further detail. For example, future studies could explore additional characteristics and experiences like gender, power, career variety, etc. to extend upper echelons literature (Abt and KnyphausenAufseß 2017; Menz 2012; Smith 2015; Steffensen et al. 2019). Second, our results show a contrary effect of role and company tenure, which indicates two types of CHROs. This classification into CHRO role gorilla and CHRO firm dinosaur offers ample research opportunities: what other characteristics do these two types have? What are the antecedents? Does this typification only apply to CHROs or to other TMT members as well? Third, additional studies on the interface between CHROs and their CEOs or TMTs would be beneficial. For instance, research on the Chief Operating Officer (COO) reveals that the "upper echelon perspective suggests that the presence of a COO will benefit TMT information-processing" (Marcel 2009, p. 
651). In line with this, we call for future research to investigate the exchange mechanisms between CHROs and their TMTs from an information-processing perspective. Fourth, one limitation of this study might be that all subdimensions of firm social performance are equally weighted across all industries. It might be beneficial for future research to investigate the different weightings of the seven subdimensions across their effect in various industries. Lastly, our study is restricted to U.S. firms. Biemann and Wolf (2009) demonstrate that typical career patterns vary significantly across different countries. Examining the CHRO role and its link to various firm outcomes in different labor markets is another promising avenue for research. Overall, we hope to stimulate research on the CHRO role and its implications for firms.

Funding Open Access funding enabled and organized by Projekt DEAL. Not applicable.

Data availability Manually collected data from multiple secondary data sources (annual Form 10-Ks or proxy statements filed with the Securities Exchange Commission; S\&P Capital IQ's ExecuComp database; Compustat; Thomson Reuters Datastream, category ESG, Asset4; LinkedIn; Bloomberg; company websites).

Code availability Not applicable.

\section{Declarations}

Conflict of interest All authors declare that they have no competing interests.

Open Access This article is licensed under a Creative Commons Attribution 4.0 International License, which permits use, sharing, adaptation, distribution and reproduction in any medium or format, as long as you give appropriate credit to the original author(s) and the source, provide a link to the Creative Commons licence, and indicate if changes were made. The images or other third party material in this article are included in the article's Creative Commons licence, unless indicated otherwise in a credit line to the material. If material is not included in the article's Creative Commons licence and your intended use is not permitted by statutory regulation or exceeds the permitted use, you will need to obtain permission directly from the copyright holder. To view a copy of this licence, visit http://creativecommons.org/licen ses/by/4.0/.

\section{References}

Abt M, Knyphausen-Aufseß zu D (2017) Chief human resources officers on top management teams: an empirical analysis of contingency, institutional, and homophily antecedents. Bus Res 10(1):49-77. https://doi.org/10.1007/s40685-016-0039-2

Aiken LS, West SG (1991) Multiple regression: testing and interpreting interactions. Sage Publications, Thousand Oaks

Angwin D, Paroutis S, Mitson S (2009) Connecting up strategy: are senior strategy directors a missing link? Calif Manage Rev 51(3):74-94. https://doi.org/10.2307/41166494

Anonymous (2014) Why chief human resources officers make great CEOs. Harv Bus Rev 93(12):30-32

Backes-Gellner U, Kluike M, Pull K, Schneider MR, Teuber S (2016) Human resource management and radical innovation: a fuzzy-set QCA of US multinationals in Germany, Switzerland, and the UK. J Bus Econ 86(7):751-772. https://doi.org/10.1007/s11573-015-0803-3

Ballinger GA (2004) Using generalized estimating equations for longitudinal data analysis. Organ Res Methods 7(2):127-150. https://doi.org/10.1177/1094428104263672 
Bantel KA, Jackson SE (1989) Top management and innovations in banking: does the composition of the top team make a difference? Strateg Manage J 10(S1):107-124

Barker VL, Mueller GC (2002) CEO characteristics and firm R\&D spending. Manage Sci 48(6):782-801

Becker BE, Huselid MA (2006). Strategic human resources management: where do we go from here?††. https://doi.org/10.1177/0149206306293668

Becker BE, Huselid MA, Ulrich D (2001) The HR scorecard: linking people, strategy, and performance.

Biemann T, Wolf J (2009) Career patterns of top management team members in five countries: an optimal matching analysis. Int J Human Resour Manage 20(5):975-991. https://doi.org/10.1080/09585 190902850190

Boeker W, Wiltbank R (2005) New venture evolution and managerial capabilities. Organ Sci 16(2):123133. https://doi.org/10.1287/orsc. 1050.0115

Bragaw NA, Misangyi VF (2017) The value of CEO mobility: contextual factors that shape the impact of prior CEO experience on market performance and CEO compensation. Hum Resour Manage 56(2):243-265. https://doi.org/10.1002/hrm

Bromiley P, Rau D (2016) Social, behavioral, and cognitive influences on upper echelons during strategy process: a literature review. J Manage 42(1):174-202

Campion MA, Cheraskin L, Stevens MJ (1994) Career-related antecedents and outcomes of job rotation. Acad Manage J 37(6):1518-1542

Cannella AA, Park JH, Lee HU (2008) Top management team functional background diversity and firm performance: examining the roles of team member colocation and environmental uncertainty. Acad Manage J 51(4):768-784. https://doi.org/10.5465/amr.2008.33665310

Cao Q, Simsek Z, Zhang H (2010) Modelling the joint impact of the CEO and the TMT on organizational ambidexterity. J Manage Stud 47(7):1272-1296

Carpenter MA, Sanders WG (2004) The effects of top management team pay and firm internationalization on MNC performance. J Manage 30(4):509-528

Carpenter MA, Geletkanycz MA, Sanders WG (2004) Upper echelons research revisited: antecedents, elements, and consequences of top management team composition. J Manage 30(6):749-778

Chahyadi C, Abusalim B (2011) The role of education and experience in CFO career and compensation. J Account Financ 20:20

Charan R, Barton D, Carey D (2009) People before strategy: a new role for the CHRO

Chatterjee S, Hadi AS (2000) Regression analysis by example. Wiley, New York

Chatterjee A, Hambrick DC (2007) It's all about me: narcissistic chief executive officers and their effects on company strategy and performance. Adm Sci Q 52(3):351-386

Chen G, Huang S, Meyer-Doyle P, Mindruta D (2020) Generalist vs specialist CEOs and acquisitions: two-sided matching and the impact of CEO characteristics on firm outcomes. Strateg Manage J. https://doi.org/10.1002/smj.3258

Chi W, Lisic LL, Pavzner M (2010) Online early-preprint of accepted manuscript preprint accepted manuscript. J Int Account Res 90(4):1395-1435. https://doi.org/10.2308/accr-50982

Chiappetta C (2019) Preparing to lead the future of HR: 3 steps to becoming a CHROIHRCI

Child J (1972) Organizational structure, environment and performance: the role of strategic choice. Sociology 6(1):1-22. https://doi.org/10.1177/003803857200600101

Cho TS, Hambrick DC (2006) Attention as the mediator between top management team characteristics and strategic change: the case of airline deregulation. Organ Sci 17(4):453-469

Cho SY, Kim SK (2017) Horizon problem and firm innovation: the influence of CEO career horizon, exploitation and exploration on breakthrough innovations. Res Policy 46(10):1801-1809. https:// doi.org/10.1016/j.respol.2017.08.007

Chung D, Kang M (2018) Characteristics of chief technology officers and radical innovation. Int J Innov Technol Manage 16(4):1950026. https://doi.org/10.1142/s0219877019500263

Cohen DJ (2015) HR past, present and future: a call for consistent practices and a focus on competencies. Hum Resour Manage Rev 25(2):205-215. https://doi.org/10.1016/j.hrmr.2015.01.006

Crossland C, Hiller NJ, Zyung J, Hambrick DC (2014) Ceo career variety : effects on firm-level. Acad Manage J 57(3):652-674. https://doi.org/10.5465/amj.2012.0469

Cyert RM, March JG (1963) A behavioral theory of the firm. Prentice-Hall, Englewood Cliffs

Donkin R (1999) Personnel: still struggling for a strategic role. Financ Times

Ferris GR, Hochwarter WA, Buckley MR, Harrell-Cook G, Frink DD (1999) Human resources management: some new directions

Finkelstein S, Boyd BK (1998) How much does the CEO matter? The role of managerial discretion in the setting of CEO compensation. Acad Manage J 41(2):179-199 
Finkelstein S, Hambrick DC (1990) Top-management-team tenure and organizational outcomes: the moderating role of managerial discretion. Admin Sci Q 35(3):484-503

Flickinger M, Gruber-Mücke T, Fiedler M (2013) The linkage between human resource practices and organizational ambidexterity: an analysis of internal labor market dynamics in a port-of-entry context. J Bus Econ 83(8):923-946. https://doi.org/10.1007/s11573-013-0671-7

Flood PC, Fong C-M, Smith KG, O'regan P, Moore S, Morley M (1997) Top management teams and pioneering: a resource-based view. Int J Hum Resour Manage 8(3):291-306. https://doi.org/10.1080/ 095851997341658

Fu R, Tang Y, Chen G (2020) Chief sustainability officers and corporate social (Ir)responsibility. Strateg Manage J 41(4):656-680. https://doi.org/10.1002/smj.3113

Garms FP, Engelen A (2019) Innovation and R\&D in the upper echelons: the association between the CTO's power depth and breadth and the TMT's commitment to innovation. J Prod Innov Manage 36(1):87-106. https://doi.org/10.1111/jpim.12441

Geiger MA, North DS (2006) Does hiring a new CFO change things? An investigation of changes in discretionary accruals. Account Rev 81(4):781-809

Georgakakis D, Heyden MLM, Oehmichen JDR, Ekanayake UIK (2019) Four decades of CEO-TMT interface research: a review inspired by role theory. Leadership Q 20:14

George JM, Zhou J (2001) When openness to experience and conscientiousness are related to creative behavior: an interactional approach. J Appl Psychol 86(3):513-524

Germann F, Ebbes P, Grewal R (2015) The chief marketing officer matters! J Mark 79(3):1-22. https:// doi.org/10.1509/jm.14.0244

Gietzmann M, Marra A, Pettinicchio A (2016) Comment letter frequency and CFO turnover. J Acc Audit Financ 31(1):79-99. https://doi.org/10.1177/0148558X15579493

Gioia DA, Manz CC (1985) Linking cognition and behavior: a script processing interpretation of vicarious learning. Acad Manage Rev 10(3):527-539. https://doi.org/10.5465/amr.1985.4278987

Gray CL (2000) What does it take to become a CFO?-ProQuest. J Account 20:20

Greene WH (2003) No title. Econometric analysis, 5th ed

Grimm CM, Smith KG (1991) Research notes and communications management and organizational change: a note on the railroad industry. Strateg Manage J 12(7):557-562

Grühn B, Strese S, Flatten TC, Jaeger NA, Brettel M (2017) Temporal change patterns of entrepreneurial orientation: a longitudinal investigation of CEO successions. Entrep Theory Pract 41(4):591-619

Guadalupe M, Li H, Wulf J (2012) Who lives in the C-suite? Organizational structure and the division of labor in top management. SSRN. https://doi.org/10.2139/ssrn.2179524

Hambrick DC (2007) Upper echelons theory: an update. Acad Manage Rev 32(2):334-343

Hambrick DC, Cannella AA (2004) CEOs who have COOs: contingency analysis of an unexplored structural form. Strateg Manage J 25(10):959-979

Hambrick DC, Fukutomi GD (1991) The seasons of a CEO's tenure. Acad Manage Rev Acad Manage 16(4):719-742. https://doi.org/10.5465/AMR.1991.4279621

Hambrick DC, Mason PA (1984) Upper echelons: the organization as a reflection of its top managers. Acad Manage Rev 9(2):193-206

Hambrick DC, Geletkanycz MA, Fredrickson JW (1993) Top executive commitment to the status quo: some tests of its determinants. Strateg Manage J 14(6):401-418. https://doi.org/10.1002/smj.42501 40602

Hamori M, Koyuncu B (2015) Experience matters? The impact of prior CEO experience on firm performance. Hum Resour Manage 54(1):23-44. https://doi.org/10.1002/hrm

Hausman JA (1978) Specification tests in econometrics. Econom Soc 46(6):1251-1271. https://doi.org/ $10.2307 / 1913827$

Hendricks KB, Hora M, Singhal VR (2014) An empirical investigation on the appointments of supply chain and operations management executives. Manage Sci 61(7):1562-1583. https://doi.org/10. 1287/mnsc.2014.1987

Heyden MLM, Reimer M, Van Doorn S (2017) Innovating beyond the horizon: CEO career horizon, top management composition, and R\&D intensity. Hum Resour Manage 56(2):205-224. https://doi. org/10.1002/hrm. 21730

Hoffman JJ, Lheureux RA, Lamont BT (1887) The effect of "inner" and "outer" TMT size on the performance of international firms. Pittsburg State Univ 9(1):121-134

Hunter LW, Thatcher SMB (2007) Feeling the heat: effects of stress, commitment, and job experience on job performance. Acad Manage J 50(4):953-968. https://doi.org/10.5465/AMJ.2007.26279227

Ishrak O, Surface C (2019) Secrets of the strategic CHRO: a model for success 
Jessee T (2020) 48 HR KPIs \& metric examples (and how to implement them)

Jiang JX, Petroni KR, Yanyan Wang I (2010) CFOs and CEOs: who have the most influence on earnings management? J Financ Econ 96(3):513-526. https://doi.org/10.1016/j.jfineco.2010.02.007

Kalnins A (2018) Multicollinearity: how common factors cause Type 1 errors in multivariate regression. Strateg Manage J 39(8):2362-2385. https://doi.org/10.1002/smj.2783

Kelly LK, Macdonald B (2014) The new path to the C-suite. Human Resour Manage Int Digest 19:7. https://doi.org/10.1108/hrmid.2011.04419gaa.002

Klenke K (2003) Gender influences in decision-making processes in top management teams. Manage Decis 41(10):1024-1034. https://doi.org/10.1108/00251740310509553

Kor YY (2003) Experience-based top management team competence and sustained growth. Organ Sci 14:6. https://doi.org/10.1287/orsc.14.6.707.24867

Koyuncu B, Hamori M, Baruch Y (2016) Guest editors' introduction: CEOs' careers: emerging trends and future directions. Human Resour Manage 10:10

Krause R, Semadeni M, Cannella AA (2014) CEO duality: a review and research agenda. J Manage 40(1):252-282

Krause R, Priem R, Love L (2015) Who's in charge here? Co-CEOs, power gaps, and firm performance. Strateg Manage J 36(13):2099-2110. https://doi.org/10.1002/smj.2325

Kumar V, Jones E, Venkatesan R, Leone RP (2011) Is market orientation a source of sustainable competitive advantage or simply the cost of competing? J Mark 75(1):16-30

Lechintan A (2017) Performance magazinelHow to measure the performance of your human resources department

Lin H-C, Shih C-T (2008) How executive SHRM system links to firm performance: the perspectives of upper echelon and competitive dynamics $\dagger$. J Manage 34(5):853-881. https://doi.org/10.1177/ 0149206308318612

Mansfield ER, Helms BP (1982) Detecting multicollinearity. Am Stat 36(3a):158-160. https://doi.org/10. 1080/00031305.1982.10482818

Marcel JJ (2009) Why top management team characteristics matter when employing a Chief Operating Officer: a strategic contingency perspective. Strateg Manage J 30(6):647-658

Mcclelland P, Liang X, Barker VL (2010) CEO commitment to the status quo: replication and extension using content analysis. J Manage 36(5):1251-1277

McKinsey (2020) The new science of talent: from roles to returns. https://www.mckinsey.com/businessfunctions/organization/our-insights/the-new-science-of-talent-from-roles-to-returns

Medcof JW, Lee T (2017) The effects of the chief technology officer and firm and industry R\&D intensity on organizational performance. R\&D Manage. https://doi.org/10.1111/radm.12275

Menz M (2011) Functional top management team members. J Manage 38(1):45-80. https://doi.org/10. $1177 / 0149206311421830$

Menz M (2012) Functional Top Management Team Members: A Review, Synthesis, and Research Agenda. J Manag 38(1):45-80. https://doi.org/10.1177/0149206311421830

Menz M, Scheef C (2014) Chief strategy officers: contingency analysis of their presence in top management teams. Strateg Manage J 35(3):461-471. https://doi.org/10.1002/smj.2104

Messersmith JG, Lee JY, Guthrie JP, Ji YY (2014) Turnover at the top: executive team departures and firm performance. Organ Sci 25(3):776-793. https://doi.org/10.1287/orsc.2013.0864

Mian S (2001) On the choice and replacement of chief financial officers. J Financ Econ 60(1):143-175. https://doi.org/10.1016/S0304-405X(01)00042-3

Michel JG, Hambrick DC (1992) Diversification posture and top management team characteristics. Acad Manage J 35(1):9-37. https://doi.org/10.5465/256471

Miller D (1991) Stale in the saddle: CEO tenure and the match between organization and environment. Manage Sci 37(1):34-52

Miller G (1994) The magical number seven, plus or minus two: some limits on our capacity for processing information. Psychol Rev 20:20

Miller D, Shamsie J (2001) Learning across the Life Cycle: Experimentation and Performance among the Hollywood Studio Heads. Strateg Manage J 22:725-745. https://doi.org/10.1002/smj.171

Miner AS, Gong Y, Baker T, O’Toole J (2011) How does TMT prior experience shape strategy? A routine-based framework based on evidence from founding teams. In: The handbook of research on top management teams, p 189

Mitchell C, Ray R, van Ark B (2014) The conference board CEO challenge 2014. In: People and performance

Murphy ML (2014) Motivation and preparation can pave the path to CFO—ProQuest. J Account 20:20 
Nath P, Mahajan V (2008) Chief marketing officers: a study of their presence in firms' top management teams. J Mark 72(1):65-81. https://doi.org/10.1509/jmkg.72.1.65

Nath P, Mahajan V (2011) Marketing in the C-suite: a study of chief marketing officer power in firms' top management teams. J Mark 75(1):60-77. https://doi.org/10.1509/jm.75.1.60

Nath P, Mahajan V (2017) Shedding light on the CMO revolving door: a study of the antecedents of Chief Marketing Officer turnover. J Acad Mark Sci 45(1):93-118. https://doi.org/10.1007/ s11747-016-0478-5

Neely BH, Lovelace JB, Cowen AP, Hiller NJ (2020) Metacritiques of upper echelons theory: verdicts and recommendations for future research. J Manage. https://doi.org/10.1177/0149206320908640

Ng TWH, Feldman DC (2013) Does longer job tenure help or hinder job performance? J Vocat Behav 83(3):305-314. https://doi.org/10.1016/j.jvb.2013.06.012

Paauwe J, Boselie P (2005) HRM and performance: what next? 15(4):68-83

Poba-Nzaou P, Galani M, Tchibozo A (2020) Transforming human resources management in the age of Industry 40: a matter of survival for HR professionals. Strateg HR Rev 19(6):273-278. https://doi. org/10.1108/SHR-06-2020-0055

Posthuma RA, Campion MC, Masimova M, Campion MA (2013) A high performance work practices taxonomy: integrating the literature and directing future research. J Manage 39(5):1184-1220. https://doi.org/10.1177/0149206313478184

Prahalad CK, Bettis RA (1986) The dominant logic: a new linkage between diversity and performance. Strateg Manage J 7(6):485-501. https://doi.org/10.1002/smj.4250070602

Quigley TJ, Hambrick DC (2015) Has the "CEO effect" increased in recent decades? A new explanation for the great rise in America's attention to corporate leaders. Strateg Manage J 36:821-830

Reuters T (2015) Asset4 ESG data glossary

Rivas JL (2012) Board versus TMT international experience: a study of their joint effects. Cross Cult Manage 19(4):546-562

Samuelson W, Zeckhauser R (1988) Status quo bias in decision making. J Risk Uncertainty 1:52

Schepker DJ, Nyberg AJ, Ulrich MD, Wright PM (2018) Planning for future leadership: procedural rationality, formalized succession processes, and CEO influence in CEO succession planning. Acad Manage J 61(2):523-552

Schwenk C (1993) Management tenure and explanations for success and failure. Omega 21(4):449-456. https://doi.org/10.1016/0305-0483(93)90077-X

Scoreboard (2020) Example KPIs for human resources (HR) departments, updated for 2020. KPI Dashboards

Shi W, Zhang YA, Hoskisson RE (2018) Examination of CEO-CFO social interaction through language style matching: outcomes for the CFO and the organization. Acad Manage J. https://doi.org/10. 5465/amj.2016.1062

Simsek Z (2007) CEO tenure and organizational performance: an intervening model. Strateg Manage J 28(6):653-662. https://doi.org/10.1002/smj.599

Smith RR (2015) Human capital in the human resource function: the positioning and impact of the chief human resource officer

Snell SA, Youndt MA (1995) Human resource management and firm performance: testing a contingency model of executive controls. J Manage 21:25

Steffensen DS, Ellen BP, Wang G, Ferris GR (2019) Putting the "management" back in human resource management: a review and agenda for future research. J Manage 45(6):2387-2418. https://doi.org/ $10.1177 / 0149206318816179$

Steinbach AL, Holcomb TR, Holmes RM, Devers CE, Cannella AA (2016) Top management team incentive heterogeneity, strategic investment behavior, and performance: a contingency theory of incentive alignment. Strateg Manage J 38(8):804-828

Stoker JI, Grutterink H, Kolk NJ (2012) Do transformational CEOs always make the difference? The role of TMT feedback seeking behavior. Leadersh Quart 23(3):582-592. https://doi.org/10.1016/j. leaqua.2011.12.009

Su ZX, Wright PM, Ulrich MD (2018) Going beyond the SHRM paradigm: examining four approaches to governing employees. J Manage 44(4):1598-1619. https://doi.org/10.1177/0149206315618011

Tanikawa T, Jung Y (2016) Top management team (TMT) tenure diversity and firm performance: Examining the moderating effect of TMT average age. Int J Organ Anal 24(3):454-470. https://doi.org/ 10.1108/IJOA-02-2014-0739

Ulrich D (1997) Human resources champion. The Human Resource Champio 
Van Doorn S, Heyden MLM, Volberda HW (2017) Enhancing entrepreneurial orientation in dynamic environments : the interplay between top management team advice-seeking and absorptive capacity. Long Range Plan 50(2):134-144

Velte P (2016) Women on management board and ESG performance. J Glob Responsibil 7(1):98-109. https://doi.org/10.1108/jgr-01-2016-0001

Veltri S, Mazzotta R, Rubino FE (2021) Board diversity and corporate social performance: does the family firm status matter? Corp Soc Responsibil Environ Manage 2020:1-16. https://doi.org/10.1002/ csr. 2136

Wang G, Holmes RM, Oh IS, Zhu W (2016) Do CEOs matter to firm strategic actions and firm performance? A meta-analytic investigation based on upper echelons theory. Pers Psychol 69(4):775-862

Wehner MC, Kabst R, Meifert M, Cunz LM (2012) Der Personalverantwortliche als strategischer PartnerHR managers as strategic partner. Z Betriebswirt 82(9):913-933. https://doi.org/10.1007/ s11573-012-0613-9

Weisberg J (1996) The impact of general and specific human capital levels. Int J Manpower 17:25

Weng DH, Lin Z (2014) Beyond CEO tenure: the effect of CEO newness on strategic changes. J Manage 40(7):2009-2032. https://doi.org/10.1177/0149206312449867

White H (1980) A heteroskedasticity-consistent covariance matrix estimator and a direct test for heteroskedasticity. Econometrica 48(4):817-838

Wiedeck C, Engelen A (2018) The copycat CMO: firms' imitative behavior as an explanation for CMO presence. J Acad Mark Sci 46(4):632-651. https://doi.org/10.1007/s11747-017-0533-X

Wiersema MF, Bantel KA (1992) Top management team demography and corporate strategic change. Acad Manage J 35(1):91-121. https://doi.org/10.2307/256474

Workforce Partnership Staff (2019) From HR to the C-suite: what it takes to become CHRO

Wright PM, Gardner TM, Moynihan LM (2003) The impact of HR practices on the performance of business units. Hum Resour Manage J 13(3):21-36. https://doi.org/10.1111/j.1748-8583.2003.tb000 96.x

Wright PM, Boudreau JW, Pace D, Sartain L, McKinnon P, Antoine R (2011) The chief HR officer: defining the new role of human resource leaders

Zhang Y (2006) The presence of a separate COO/president and its impact on strategic change and CEO dismissal. Strateg Manage J 27(3):283-300. https://doi.org/10.1002/smj.517

Zona F (2016) Agency models in different stages of CEO tenure: the effects of stock options and board independence on R\&D investment. Res Policy 45(2):560-575. https://doi.org/10.1016/j.respol. 2015.10.012

Zorn DM (2004) Here a chief, there a chief: the rise of the CFO in the American firm 69:345-364https:// doi.org/10.1177/000312240406900302

Publisher's Note Springer Nature remains neutral with regard to jurisdictional claims in published maps and institutional affiliations. 